\title{
Gold Rush Doc
}

\author{
By Chaungey D. Leake \\ University of Texas Medical Branch
}

Appropriate as a greeting to Henry Sigerist on his Sixtieth Birthday is an account of a pioneer California scientist and physician, who made many notable contributions, but whose work is now practically forgotten. The appropriateness lies in the proposition that Henry Sigerist is also a daring intellectual pioneer, but there the matter stops. Henry Sigerist's contributions are so firmly established that they have become part of our general cultural program, and form a substantial portion of that body of opinion and interpretation which is maintaining so well the high idealism and tradition of the medical profession. All Doctor SIGERIST's friends unite in extending hearty wishes to him for many more years of pioneer exploration in the history and philosophy of medicine, and for rich satisfactions for him in that effort.

Most people believe that scientific or medical fame is merited by achievement. This is no more the case for scientists and medical men than for any other class of people. Fame, like notoriety, results from publicity, and often the line between the two is slender. One of the pleasures of historical study is the discovery of some forgotten genius who merits remembrance. Nevertheless, it is difficult to add a new name, no matter how worthy, to the tightly arranged and accustomed lines of history.

Consider that gold rush doctor who was California's first great scientist. Here was a man well recognized by his scientific and medical colleagues abroad and in this country before he took the overland trail to California. In Sacramento and San Francisco he was an intellectual leader and held many posts of honor and distinction. He was a pioneer fact-finding scientist with many interesting and practical publications in chemistry, pharmacology, physiology, medicine, geology, biology and meteorology. Significantly, he was a bachelor, and a lone wolf. Few saw his contributions or referred to them. He probably had little respect for the frontier scientists and medical man with whom he had to associate, and since he had little power or authority, they saw no reason to afford him any appreciative regard. The result is that he and his work are now forgotten. 


\section{California Character}

Robert Louis Stevenson's account of the Silverado Squatters is a brave and cheerful record of what was in fact a very trying period of his life. $\mathrm{He}$ had just been married in San Francisco, and with a very uncertain future he went to live with his bride and her small son on the slopes of Mount St. Helena above the Toll House at the summit of the stage road. During the few months of the family's camping in the abandoned mine shacks, diphtheria and tuberculosis visited them. There seems to be no record of the doctor who attended them in these crises. At the time, the summer of 1880 , the nearest doctor was California's first great scientist who was operating a tuberculosis sanitarium on the summit of Monte Sol, a hill to the east of Mount St. Helena. One would like to think that California's first great scientist helped the Stevensons in some of their difficulties at that time, and that some part of Stevenson's magnificent tribute to physicians might have been inspired by this same man. But there is no evidence that it was so.

Very few people know anything at all about California's first great scientist. When some of us who are interested in his work went up to search for his grave in the cemetery in Middletown, we could fine only a few of the older residents who recalled anything about him. We were told that he was a tall and quiet gentleman who loved flowers and who was very generous toward the sick. He didn't practice but never turned a sick person away and never sent a bill. The house he built in Middletown still stands. In it went forward remarkable chemical and physiological studies, but his neighbours knew nothing of them. We asked what kind of a reputation he had in Middletown. Those who remembered him seemed a little reluctant to say. Finally, one gentle old lady ventured the remark that he was what used to be called a "chaser". This surprising admission gave us a clue regarding his remarkable career. At his death in 1893 the inventory of his estate was filed in the Court House in Lakeport. When we examined it, we found that his house and lot in Middletown was valued at $\$ 600.00$, his horse and buggy at $\$ 25.00$, his gold watch at $\$ 25.00$, but that his scientific and medical books, instruments and equipment were listed as having no value. These were, in fact, the most important things he left, but there seems to be no indication as to where they have gone.

California's first great scientist came to Sacramento from St. Louis by the overland route in 1850. He had arrived at St. Louis in 1847 and had at 
once been appointed Professor of Anatomy and Surgery at the St. Louis University Medical College. Already his work was highly regarded, and he seems to have joined the life of the sprawling, rapidly growing Mississippi River town with vigor and enthusiasm. There seemed to be no regrets on his departure, however. The Annual Announcement of the St. Louis University Medical College for 1850 simply said that "the post vacated by Dr. Blake has been filled by Dr. EDwards". The announcement in 1847 had been most eulogistic of Dr. Blake. James Blake came to St. Louis from London. Here again his work had attracted wide attention and he seems to have been well known, and appreciated in scientific and medical centers. One cannot help but feel that California's first great scientist, JAMES BlaKe, left a promising career in London to come to St. Louis, and then left a promising career there to come to California, for some variation of the same reason that led the gentle old lady of Middletown to recall him as a "chaser".

\section{Early Career}

JAmes Blake was born in Gosport, England, on July 14, 1815. In his boyhood he must have thrilled at the bustling sights of his seaport home. He went to the University of London. Here he embarked on a medical career and came under the influence of leading British chemists and physiologists, particularly Thoman Graham (1805-1869) and William Sharpey (1802-1880). He apparently studied in France, perhaps with F. MAGENDIE (1783-1855), the first great modern physiologist and pharmacologist. His first published work in 1839 refers to physiological instruments which he brought from Paris.

This first scientific work of BLAKE's was quite remarkable. It was a pioneer account of the physiological effects produced by injecting chemicals directly into the blood stream of an animal. BLAKE measured particularly the action on blood pressure, pulse, and respiration and described the general nervous response. He used solutions of such recently isolated alkaloids as morphine, nicotine and strychnine and other chemical agents as well. Some injections were made into the arteries, others into the veins. By determining accurately the time period from the moment of injection until effects were noticed, he made the first estimations of circulation time.

Following this, a series of extraordinary reports were made by BLAKE before the Royal Society, the British Association for the Advancement of Science, and various medical organizations. BLAKE took the thesis that there 
must be some relation between the chemical make-up of drugs and the effects these drugs produce on living things. By using chemicals whose constitutions were well established, such as the inorganic salts, and by studying carefully their effects on living things, BLAKE felt it might be possible to obtain some clue as to the physical-chemical make-up of living tissue. By 1846 BLAKE had come to three quite remarkable conclusions: (1) that the characteristic physiological effect of an inorganic compound in solution was produced by the electro-positive element; (2) that with increase in atomic weight of the electro-positive element in a series of inorganic compounds there is an increase in toxicity; and (3) that the characteristic physiological effects of the electro-positive elements tend to reappear as one goes up the series with increasing atomic weight. He claimed that the effects of the various inorganic compounds on the body are related chiefly to the "isomorphous" properties of the electropositive element, that is, to the crystal structure, and that the grouping of the elements on the basis of physiological action coincides with their isomorphous groupings. BLAKE also showed that the electro-negative elements possess similar physiological properties, and that they could also be arranged in groups on the basis of their physiological action. When one examines the groups of the elements made by BLAKE on the basis of their physiological action one cannot help but be struck by the remarkable similarity to what is called the "Periodic Table", the famous classification of the elements on the basis of their physical-chemical properties as made by the great Russian chemist, MendelejefF (1834-1901), some twenty years later. Blake's reports attracted much attention and he was obviously destined for a brilliant scientific career in Europe. That his interests were strongly medical is indicated by the fact that he became a Fellow of the Royal College of Surgeons. Then suddenly he left London and appeared in St. Louis.

\section{Blake's Clinical Career}

As a clinician, James Blake showed the same critical and skeptical scientific attitude as he displayed in his laboratory and exprimental studies. He was a careful observer, and wrote on a wide variety of clinical conditions. His clinical acumen was considerable, as indicated in his observations on the obliteration varicose veins, and on the treatment of tuberculosis. On the other hand, he was not greatly. impressed with the developing knowledge of the etiology of infectious diseases as based on the discovery of bacteria. 
His clinical discussions on diphtheria were ineffectual. BLAKE's most important clinical contribution was his development of the open-air rest treatment for tuberculosis. Here he anticipated by many years the studies and writings which are usually credited with introducing this regimen.

BLAKE's first clinical report was made in 1839 in the form of a letter to the Editor of the Lancet. Referring to the treatment of varicose veins, by obliteration, BLAKE concludes from experiments that "by arresting the circulation in the vessel for a few hours (twelve to sixteen); by passing a couple of needles under it and using the twisted suture; and by the application of gentle external pressure, the slight degree of irritation, thus produced, will be sufficient to cause such an effusion of lymph and serum in the sheath of the vessel as to lead to its permanent obliteration". Although BLAKE must have had a considerable practice in London, to judge from his offices on Conduit Street, and on Pall Mall, he made few clinical publications while there. He was then more absorbed in his experimental work. In St. Lours, BLAKE noted abnormal distribution of thyroid arteries, and described filaria in the hearts of dogs.

After the long journey over the plains from St. Louis, on which BLAKE later relates that he encountered much cholera, he apparently settled into the strenuous frontier medical practice of the California Gold Rush. His offices were near the busy Sacramento wharves, and he must have had many patients among those going to and from the mines.

The first medical journal in California appeared in 1856. BLAKE at once began to write for it, contributing articles reflecting his practice. These were of a strictly clinical nature, and dealt with gun-shot wounds, diphtheria, and spontaneous rupture of the vagina in labor. BLAKE couldn't stand hypocrisy or misrepresentation on the part of his professional colleagues. He vigorously and fearlessly exposed the attempt of an unqualified colleague to cover up, by reporting as an accident, what was a mistake in technique in an alleged case of spontaneous rupture of the vagina in labor. In this exposé BLAKE makes one of the first uses in American medical literature of the theory of probability.

In 1860 appeared an astonishing report from BLAKE on the treatment of phthisis. In this communication, BLAKE vigorously denies that drugs have ever beeen of any value in tuberculosis. He asserts that the only success he has ever had in handling the disease is to have his patients go on a camping trip in a sunny, sheltered spot where they were to do no work but just to take life easily. This is the modern open-air, sunshine and rest 
treatment for tuberculosis which apparently was introduced by BLAKE twenty years ahead of those who usually receive the credit for it.

BLAKe moved to San Francisco in 1861 to become editor of the Pacific Medical and Surgical Journal. Some of his editorials were remarkable. He advocated the establishment of a Board of Health in order to control the possible entry of epidemic diseases into the port of San Francisco. One of his editorials dealing with war has a startlingly modern ring. BLAKE could see no sense in the fraternal strife then raging in this country and he very emphatically said so. It is rather astonishing to find that he was reviewing in California the outstanding medical discoveries made in Europe within a few months of their publication abroad. Before a year passed BLAKE had resigned his editorship on the grounds that the number and quality of the contributions to the journal were such as not to make it worth his while.

In 1863 Dr. H.H. Toland of San Francisco organized a Medical College, on the faculty of which Dr. BLAKE appeared as Professor of Midwifery and Diseases of Women and Children. This appointment may have resulted from his keen analysis of the notorious Sacramento case of alleged spontaneous rupture of the vagina in labor. BLAKE seems to have relinquished his academic position during the squabble when the Toland Medical College became the Medical School of the University of California in 1873. But he seems later to have served on the faculty again. We have record of only two of his activities at the old medical building on Stockton Street-his inaugural address at the beginning of his teaching career and an address to one of the graduating classes. Dr. Joseph P. WidNey, of the class of 1865, one of the Medical School's first graduates, and a leader in medical affairs in Los Angeles, stated that Dr. BlaKe was one of his finest teachers. Surprisingly, Dr. WIDNEy said that Blake was not at all "scientific" in his teaching but very practical, and that his example of gentleness and dignity made a great impression on his students.

In connection with his academic career as Professor of Midwifery and Diseases of Women and Children, BLAKE reported on infant mortality, on typhoid fever in children, and on foreign bodies in the uterus. He also made several case reports relating to obstetrics and gynecology, and described a new form of pessary. It is remarkable that BLAKE made no significant contributions to drug therapy, in spite of his wide experimental studies in this field. The fundamental nature of his investigations may have deterred him from seeking practical applications. 


\section{BLAKE's Scientific Interests}

BLAKE's interest in active medical practice lasted little more than a decade. Probably he began to receive some moneys from home, but unlike most of the large army of "remittance men" in California, he seems to have turned his energies to productive efforts. He became very interested in the California Academy of Science, and his natural scientific genius flourished in all directions. He made chemical analyses of drinking waters, new ores and minerals, the biological fluids in new species of fishes, and of grapes. The latter was for the purpose of determining the fitness of various kinds of grapes for making wines. BLAKE stated that those grapes with the highest organic acid and aldehyde content would be found to make the best wines. He became President of the California Academy of Science in 1868 and served in this capacity for four years.

BLAKE must have been very happy in this stage of his life. He seems to have traveled extensively over the western part of the United States on a series of geological studies. He was one of the pioneer geologists in the Sierra region. He made many important observations, especially in the Great Basin of Nevada. He described the various factors involved in the characteristic topography of the area, produced evidence of glacial action and of gradual land elevation. He also made anthropological studies, and analyses of earth-quakes.

About this same time, BLAKE became interested in meteorology and at his own expense established observing stations in the Sierra and in the southern part of the state. With observations from these stations and with data from other parts of the world he was bold enough to propose a general theory of climatic change which was based upon relative pressure variations in the polar regions and in the tropics. Many important zoological studies were undertaken bay him. Some of these related to the reproduction of viviparous fishes and to certain new species of marine life. He also investigated phylloxera, the widespread vineyard pest and recommended carbon bisulphide for its control.

Apparently he now found the leisure to return to the scientific studies of his earlier career in London. He began publishing again in English and French scientific journals on the relationship between the chemical constitution of various salts and the physiological effect of these compounds when introduced directly into the animal body. He must have had close contact with leading European chemists for he received from them samples of new 
and rare elements for his studies. He discovered that the complexity of physiological activity increases with the valence of an element in inorganic combination and he examined this problem in connection with a large number of compounds.

In 1876, just when BLAKE seemed to be at the height of his scientific activities in San Francisco he suddenly left the city to develop a tuberculosis sanitarium east of Mount St. Helena at the head of the Napa Valley. He found a beautiful site partially cleared by a very energetic woman named Emaline Woods. Blake seemed to have formed some sort of a partnership with Mrs. Woons. After operating the institution for four years they sold it to a prominent California family who have developed it into a beautiful estate. BLAKE thereupon moved to Middletown. Mrs. Wood moved also and lived in the house behind BLAKE. Of her, we know little except what appears on her gravestone beside BLAKE's in the Middletown Cemetery. This states that she died in 1906, that she was a native of Maine, and that her faith was in God.

At Middletown BLAKE began a series of spectroscopic experiments in connection with his studies on the relation between chemical constitution and physiological action. He must have had an excellent spectroscope, and at a time when there probably weren't more than a half dozen such instruments in this country. He felt that the molecular vibrations of molecules of chemical agents determine the physiological effect of these agents when placed in contact with living tissue, as a result of the relation between the molecular vibrations of the chemical and the vibration rates of the molecules in the living cell. The spectroscope gives some indication through spectrum absorption bands of such vibration rates.

All of BLAKE's observations were now published abroad. From Middletown he must have gone on three occasions to Europe to present personally the results of his studies before the learned societies of England, France, and Germany.

An interesting example of the unappreciated importance of BLAKE's work may be found in his studies on thallium. In 1934, in connection with the control of rodent pests by thallium-poisoned grain, an outbreak of thallium poisoning in humans occurred in Fresno. No one seemed to know much about acute thallium poisoning, although its chronic toxicity had been studied in connection with the use of its salts in cosmetics. Some of us took rather an impish delight in calling attention to the fact that BLAKE had reported upon the acute toxicity of thallium compounds in 1892 . He 
had even determined the rate of its excretion from the body, by means of the spectroscope. Of course, the publication of his work in French may have led to its neglect by American scientists.

\section{BLAKE's Influence}

The wide scope and significance of BLAKE's scientific achievements entitle him to be called "California's First Great Scientist". He came in the glamorous days of the Gold Rush and entered vigorously into the intellectual life of the new commonwealth. His theoretical contributions on the relationship between chemical constitution and physiological action inaugurated an important line of scientific investigation.

BLAKE's work seems to be little known or appreciated. His insistence that the open air rest treatment for tuberculosis is the only satisfactory method for treatment seems to have been completely overlooked at the time BLAKE himself had the experience at one of the Physiological Society meetings in England of hearing a report on the action of digitalis on the arteries which was claimed as a new discovery, when, in fact, he had described it himself fifty years previously. Dr. Henry Harris has referred to BLAKE as an intellectual of the type of Lord Jim in ConRaD's story, or of Sinclair Lewis' Arrowsmith. The fact remains that Blake was an extraordinarily versatile scientific genius. As the leading scientist of that remarkable company of glamorous adventurers who made California, he deserves wider appreciation than he has so far received.

It is the responsibility of the historians of science and medicine to note, if possible, the first person to toss pertinent new material into the stream of knowledge. BLAKE's observations on the relation of chemical constitution to biological action (biochemorphology), on meteorology, and on tuberculosis were pioneeringly significant. Perhaps Doctor Sigerist's monumental History of Medicine may have a niche for them.

\section{Reference Notes}

BLAKE's published contributions number about a hundred and are widely scattered. His early biochemorphic investigations were reported in The Edinburgh Medical and Surgical Journal and in the Proceedings of the British Association for the Advancement of Science. After coming to St. Louis, they were summarized in the American Journal of Medical Sciences (n.s. 15, 63-76, Jan. 1848). Most of BLAKE's non -medical observations are to be found in the Proceedings of the California Academy of Sciences from 1868 to 1877. His clinical reports appear chiefly in the single volume of The California State Medical Journal issued in 1856 and 1857, and in The Pacific Medical and Surgical Journal from 1858 to 1879. 
BLAKE's later biochemorphic reports are to be found mainly in The Journal of Anatomy and Physiology, The Journal of Physiology, and in Comptes rendus hebdomadaires des séances de l'Académie des sciences.

An accuunt of James Blake may be found in Henry Harri's California's Medical Story (San Francisco, J.W. Stacey, 1932, p. 342-7). A review of his clinical career appears in California and Western Medicine (47, 405-7, 1937).

\title{
Das «Buch über die Wiederkäuer» («Merycologia») von Johann Conrad Peyer, eine der geschichtlichen Grundlagen der heutigen Haustierphysiologie
}

\author{
Von Nikolaus Mani, Basel
}

Ein beträchtlicher Teil der biologischen Forschung des 17. Jahrhunderts betrifft die Anatomie und Physiologie des Magendarmkanals. Aselli entdeckte 1622 die Chylusgefäße und begründete in zahlreichen Versuchen die experimentelle Methode für das Studium der Darmresorption. Pecquet beschrieb 1647 den Ductus thoracicus und die Cisterna chyli beim Hunde. Mit dieser Entdeckung versetzte er der noch immer fest verwurzelten Galevischen Resorptionstheorie den Todesstoß. Nicht den Gekrösevenen, sondern ausschließlich den Venae lacteae, den Chylusgefäßen, schrieb man nun die Aufnahme des Nahrungsbreies zu.

Die Entdeckung des Blutkreislaufes durch HARvey (1628) zeigte die Blutversorgung aller Organe in völlig neuem Lichte und nötigte die Ärzte und Naturwissenschafter zu einer generellen Überprüfung der GALENischen Physiologie.

Die anatomische Beschreibung der Ausführungsgänge des Pankreas (Wirsung 1641) und der Speicheldrüsen (Wharton 1655, Stensen 1669) lenkte das Interesse der Forscher auf das Studium der Drüsenfunktion und Drüsensekrete.

Dann folgte das klassische Werk Malpighis über die Struktur der Eingeweide. Die altehrwürdigen, von Aristoteles, Erasistratos und Galen übereinstimmend zu den blutartigen Körperteilen gezählten Viscera wurden mit einem Schlage in die neuentdeckte Gruppe der Drüsenorgane eingereiht. 